\title{
The Situation of Regional Concentration of Tomato Foreign Trade in Turkey
}

\author{
Şeyma Arslan ${ }^{1, a, *}$, Hasan Arısoy ${ }^{1, b}$, Zuhal Karakayacı ${ }^{1, c}$ \\ ${ }^{1}$ Department of Agricultural Economics, Faculty of Agriculture, Selçuk University, 42250 Konya, Turkey
}

*Corresponding author

\begin{tabular}{l|l}
\hline A R T I C E I N F O & A B S T R A C T \\
\hline Research Article & $\begin{array}{l}\text { World trade in agricultural products, tends to increase. Turkey is among the countries in foreign trade } \\
\text { advantages with its agricultural potential. As one of the most important tomato producer countries, } \\
\text { monitoring of developments in the world tomatoes trade is extremely important for Turkey. The aim } \\
\text { of this study was to evaluate Turkey's position in world tomato trade. The developments of tomato } \\
\text { foreign trade between Turkey and importer countries were analysed using Trade Intensity Analysis } \\
\text { Method. Turkey supplied \% 75 of total tomato exports to Russia. Ukraine, Saudi Arabia, Iraq, Syria } \\
\text { and Israel are important markets for tomato export. The epidemic (Covid-19 virus) has also been } \\
\text { reflected in the international trade balances in tomato production. Giving importance to Turkey's } \\
\text { political relations and to boost its exports by providing market diversity, it is important for the } \\
\text { Accepted : } 25 / 01 / 2022 \\
\text { sustainability of tomato exports. In this context, market researches should be conducted specially to } \\
\text { find and entrance into new markets. Besides the fresh tomato, the activities for the export of tomato } \\
\text { paste and canned tomato should be implemented. }\end{array}$ \\
$\begin{array}{l}\text { Keywords: } \\
\text { Regional concentration }\end{array}$ &
\end{tabular}

Turkey

Foreign trade

Concentration coefficient

Türk Tarım - Gıda Bilim ve Teknoloji Dergisi, 10(2): 280-289, 2022

\section{Türkiye'nin Domates Dış Ticaretindeki Bölgesel Yoğunlaşma Durumu}

\begin{tabular}{|c|c|}
\hline M A K A L E B İ L G İ S İ & Ö Z \\
\hline $\begin{array}{l}\text { Geliş : 15/10/2021 } \\
\text { Kabul : 25/01/2022 } \\
\\
\text { Anahtar Kelimeler: } \\
\text { Domates } \\
\text { Bölgesel yoğunlaşma } \\
\text { Türkiye } \\
\text { Diş ticaret }\end{array}$ & $\begin{array}{l}\text { Dünya tarım ürünleri ticareti, artma eğilimindedir. Türkiye, mevcut tarım potansiyeli ile dış ticarette } \\
\text { avantajlı ülkeler arasındadır. En önemli domates üreticilerinden biri olan Türkiye için dünya domates } \\
\text { ticaretinde yaşanan gelişmelerin izlenmesi son derece önemlidir. Bu çalışmanın amacı, Türkiye'nin } \\
\text { dünya domates ticaretindeki konumunun değerlendirilmesidir. Türkiye ile ithalatçı ülkeler arasındaki } \\
\text { domates ticaretin zaman içerisindeki değişim durumu, Ticaret Yoğunlaşması Analiz Yöntemi ile } \\
\text { analiz edilmiştir. Türkiye domates ihracatının \%75'ini Rusya'ya yapmaktadır. Ukrayna, Suudi } \\
\text { Arabistan, Irak, Suriye ve İsrail'de domates ihracatında önemli pazarlarıdır. Pandemi (Covid-19 } \\
\text { virüsü) domates üretiminde, uluslararası ticaret dengelerine de yansımıştır. Türkiye'nin siyasi } \\
\text { ilişkilerine önem vererek ve pazar çeşitliliği sağlayarak ihracatını artırması, domates ihracatının } \\
\text { sürdürülebilirliği için önem arz etmektedir. Bu kapsamda, özellikle yeni pazarların bulunmasına } \\
\text { yönelik pazar araştırmaları yapılmalıdır. Taze domates yanında salçalık ve konserve domates } \\
\text { ihracatına yönelik faaliyetlerin de artırması gerekmektedir. }\end{array}$ \\
\hline
\end{tabular}

Yoğunlaşma katsayısı 


\section{Introduction}

Turkey is one of the countries with high agricultural potential and is one of the rare countries where hundreds of annual and perennial crops are grown. Due to the different geographical and ecological conditions, it is possible to produce hundreds of products with different climate and soil demands. A wide variety of fruits and vegetables are grown throughout the country due to the high degree of intensity and, accordingly, the high profitability (Bayramoğlu et al., 2009).

Today, Turkey is in the top ten rankings in the world in the production of many agricultural products. According to the 2019 data of the Ministry of Agriculture and Forestry of Turkey, Turkey ranked first in the world in the production of hazelnuts, cherries, figs and apricots, second in the production of quince, poppy seeds, melons and watermelons, third in the production of lentils, pistachios, chestnuts, sour cherries and cucumbers, walnuts, olives, apples, tomatoes, It ranks fourth in eggplant, spinach and pepper production. Turkey is one of the important countries in tomato production due to its favourable climatic conditions. Turkey's total tomato production in recent years has exceeded 12.7 million tons. While Turkey ranks third in the world with this production, it meets $7.2 \%$ of the total tomato production in the world according to 2018 data. Tomatoes meet about $40-45 \%$ of Turkey's vegetable production (Anonymous, 2018a).

In Turkey, tomato ranks first among vegetables in terms of production, consumption and value in economy. Tomato is one of the important sources of income for farmers in growing regions (Çelik and Özbay, 2015). Tomatoes are also considered as one of the important indispensable agricultural products in human nutrition. In addition to the fresh consumption of tomatoes, the fact that it has a wide variety of uses in the food industry such as frozen tomato paste, sauce, ketchup, pickles, tomato juice, tomato puree, peeled tomatoes, sliced tomatoes, diced tomatoes, increases its importance (Ertürk and Çirka, 2015).

In Turkey, fresh tomato production is carried out in the open (in the field) and in greenhouses, and in the as a raw material for the processing industry. Turkey's production has been increasing every year for many years. This situation is confirmed by the fact that tomato production was 8.5 million tons in 2001, increasing by $50 \%$ in 2017 to 12.75 million tons.

It has been determined that the increase in tomato production may be due to factors such as the improvement in the use of agricultural inputs and there was a 2.16-fold increase in tomato productivity in the 1960-1999 period (Kaymak et al., 2005). Productivity can be further increased by using inputs and new techniques in tomato production. In recent years, the spread of tomato cultivation under cover has provided an increase in production and productivity as well as season expansion. Domestic and foreign marketing opportunities of tomatoes, which are produced in high quantities, must be evaluated. Having tomatoes in domestic and foreign markets in different seasons will increase Turkey's competitiveness.

On the other hand, it is possible to increase tomato production both in season (in the open) and out of season (greenhouse) in Turkey.
The year 2014 of the United Nations Food and Agriculture Organization (FAO)

according to the data; Tomato is the most exported fresh vegetable in the world. For example, the global foreign trade volume of fresh tomatoes in 2013 and 2014 was around 7.9 and 8.2 billion dollars, respectively, and their share in the total world fresh vegetable exports was $25 \%$. The Netherlands is the world leader in tomato exports with an export of 2.0 billion dollars and a share of $25 \%$, followed by Mexico with 1.8 billion dollars and a share of $21 \%$, Spain with a share of 1.3 billion dollars and $\% 15$, and with a share of 480 million dollars and $5 \%$. followed by Morocco (FAO,2014). Turkey is one of the leading exporters and as of 2014, FAO ranked fifth in the world by exporting approximately 500 thousand tons and 426 million dollars' worth of tomatoes.

The year 2014 of the United Nations Food and Agriculture Organization (FAO)

according to the data; The share of tomato exports in Turkey's total export of fresh vegetables is $40 \%$ on the amount and $55 \%$ on the monetary value. The amount of exported tomatoes is $4 \%$ of our total production and $6 \%$ of our table tomato production. The Russian Federation has the largest share in exports, followed by Ukraine, Bulgaria, Romania and Iraq.

The share of Russia alone is about $65 \%$. If we do not count the crisis with the Russian Federation in 2016, it is seen that tomato exports have stabilized and developed in a healthy way in recent years. Considering that a significant part of the processed tomato products other than the fresh product is exported, the role of the tomato in export is better understood and the tomato becomes more meaningful.

It is important to evaluate the tomato, which has a high production amount and high sufficiency rate, in foreign trade. On the other hand, when examining the place of tomato in foreign trade, knowing what the competitive power is will increase the chance of success.

In many studies analysing the competitiveness of tomato, which is the most important in Turkey's agricultural exports, it has been concluded that Turkey has "competitive power in tomato exports". This should be taken seriously.

The aim of the study, which was carried out by evaluating all these reasons, is to evaluate the place of Turkey in the world tomato trade. In addition, it is to examine the change in the value and direction of the trade flow between Turkey and tomato importing countries on an annual basis. Thus, it will be possible to determine what kind of share Turkey has in the current and potential markets and the change in this share over time.

\section{Material and Method}

The main material of the study was the secondary data obtained from the International Trade Center (ITC - Trade Map) database. In the Harmonized Commodity Description and Code System (HS Code), the code number of the tomato product is 0702 . The data used in the research are annual and cover the period 2001-2018. In addition, the documents of institutions such as the United Nations Food 
and Agriculture Organization (FAO), the Turkish Statistical Institute (TUIK) and scientific studies on the subject were also used.

Many methods close to each other are used in the analysis of international commercial developments. In this study, the "Trade Concentration Analysis Method", which reveals the course of bilateral trade relations, was used. With this method, the change in the trade shares between the exporting country and the importing country and the trade intensity between the two countries are revealed.

The concept of trade concentration is based on the comparison of the trade relationship between two countries with other countries. In other words, if the export/import ratio of country $A$ to country $B$ is above the (world) export/import average of all other countries to country B, it is accepted that country $\mathrm{A}$ is in export/import concentration with country B (Froment and Zighera, 1964; Arisoy et al., 2014).

Concentration(Regionalization)Coefficient: $=\frac{X i k j \times X k}{X j k \times X i k}$

Where;

$\mathrm{Xikj}=$ Export value (1000 USD) of product $\mathrm{k}$ from country $j$ to country $i$

$\mathrm{Xk}=$ World foreign trade value of product $\mathrm{k}$

$\mathrm{Xjk}=$ Export value of product $\mathrm{k}$ of country $\mathrm{j}$

$\mathrm{Xik}=$ The $\mathrm{k}$ product of country $\mathrm{i}$ is expressed as the import value

A concentration coefficient greater than 1 indicates that the importing country has shifted to the exporting country's product above the theoretically expected rate. In a broader expression; The fact that the index value is greater than " 1 " indicates that country "a" exports and imports to country " $b$ " above the world average, in other words, country "a" has an intense export-import relationship with country "b". The fact that the index value is less than " 1 " shows that, unlike the first situation, the export-import relationship isnot intense compared to the world average. In this study, the concentration coefficients between Turkey and tomato exporting countries such as Russia, Iraq, Ukraine, Syria, Israel and Saudi Arabia were examined. These determined countries, according to the 2019 data of the Ministry of Agriculture and Forestry; Tomato export shares are 17.5\% with Russia, $12.9 \%$ with Iraq, $12.7 \%$ with Ukraine, $11.6 \%$ with Syria, $7.4 \%$ with Israel and $7.2 \%$ with Saudi Arabia. Tomato import shares are; $75 \%$ with Russia, $9.3 \%$ with Iraq, $6.6 \%$ with Ukraine, $1.5 \%$ with Israel.

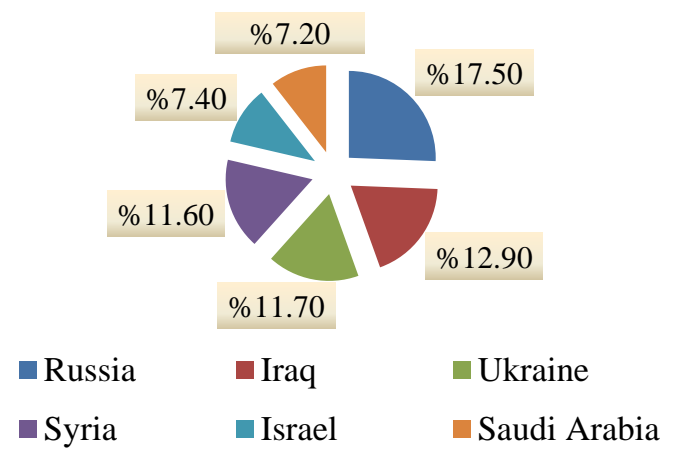

Figure 1. Important Countries in Turkey's Tomato Export
In the country selection, primarily Turkey's tomato export shares in the last 18 years were taken as a basis.

Trade concentration has been calculated for countries with a high share in tomato exports, which are given in Figure 1. Thus, it is aimed to contribute to the determination of the trade strategy between Turkey and its partners.

\section{Tomato Production and Trade \\ Production}

According to FAO 2017 data, the world tomato production, which is constantly increasing, has a $16 \%$ share in the world fresh vegetable production, which is 1.1 billion tons, with 182 million tons. In the world tomato production as of 2017 , China ranks first with a production of 59.6

million tons, India ranks second with 20.7 million tons, Turkey ranks third with 12.75 million tons and the USA ranks fourth with a production of 12.6 million tons. Being the leader in the world, China meets $32 \%$ of the total world tomato production (Figure 2 and Figure 3).

In Turkey, fresh tomato production is carried out in the open and in greenhouses, and in the open (in the field) as a raw material for the processing industry.

The amount of production in Turkey has been increasing every year for many years. This situation is confirmed by the fact that tomato production was 8.5 million tons in 2001, increasing by $50 \%$ in 2017 to 12.75 million tons (Figure 4)

When the world tomato production is analysed on the basis of countries in the last 18 years (2001-2018), Nigeria, India, China, Uzbekistan and Iran have realized the highest production increase. Turkey, on the other hand, increased its total tomato production by approximately $45 \%$ in the same period (Table 1).

\section{Trade}

Mexico ranks first in world tomato exports, while the Netherlands ranks second and Spain third. Ranking fifth, Turkey's share in exports increased by $1 \%$ from 525 thousand tons to 530 thousand tons in 2018(Figure 5). In tomato imports, with 1.8 million tons of imports, the USA ranked first with a share of $25.4 \%$ in world imports, while Germany ranked second with 731 thousand tons of imports, and Russia ranked third-with 577 thousand tons of imports (Figure 6). Turkey's imports, on the other hand, increased by $88 \%$ proportionally in 2018 compared to the previous year, increasing from 553 tons to 1041 tons. Turkey, which does not have an important place in the world ranking in the amount of tomato imports, ranks fifth in the world with its share in the amount of exports (Figure 7, Figure 8).

Russia has become the most important country in Turkey's tomato export in recent years. Russia has the largest share in exports, followed by Iraq, Ukraine, Syria, Israel and Saudi Arabia. While 30\% of Turkey's tomato exports were made to Russia in 2001, this rate increased to $65.81 \%$ in 2013 (Erturk and Cirka, 2015). Turkey's tomato export to Russia was 275 million dollars in 2014. In thelast 5 years, Turkey's tomato export to Russia has increased by $10 \%$. Along with Russia, the Middle East and Eastern European countries constitute Turkey's important market (Table 2). 


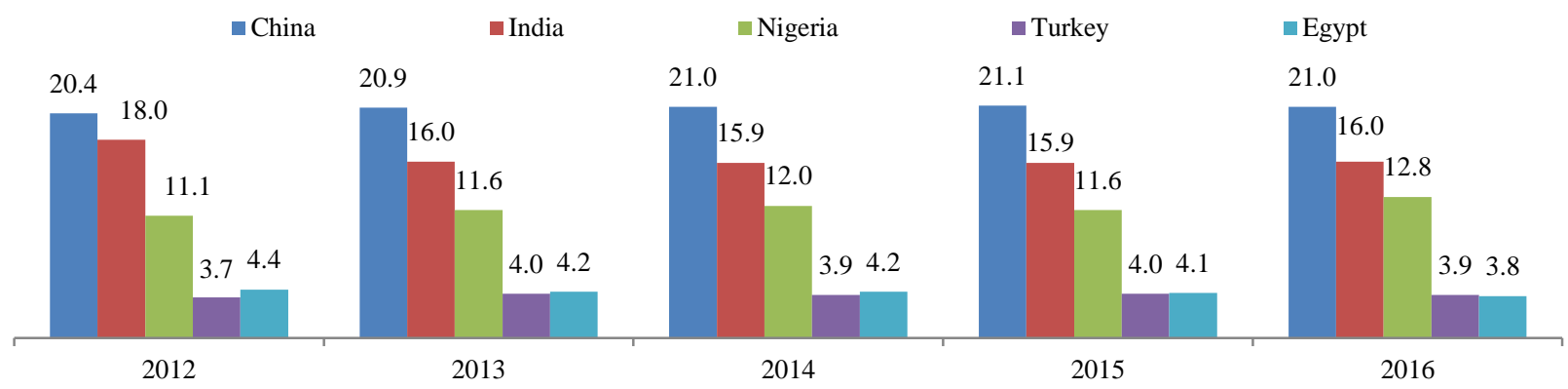

Figure 2. Major Countries İn Tomato Cultivation (\%)

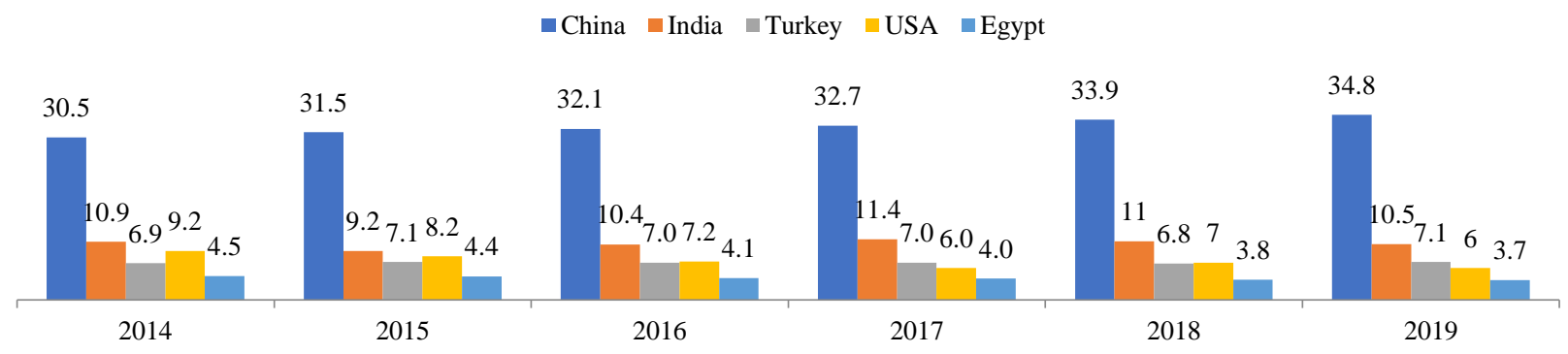

Figure 3. Important Countries İn Tomato Production (\%)

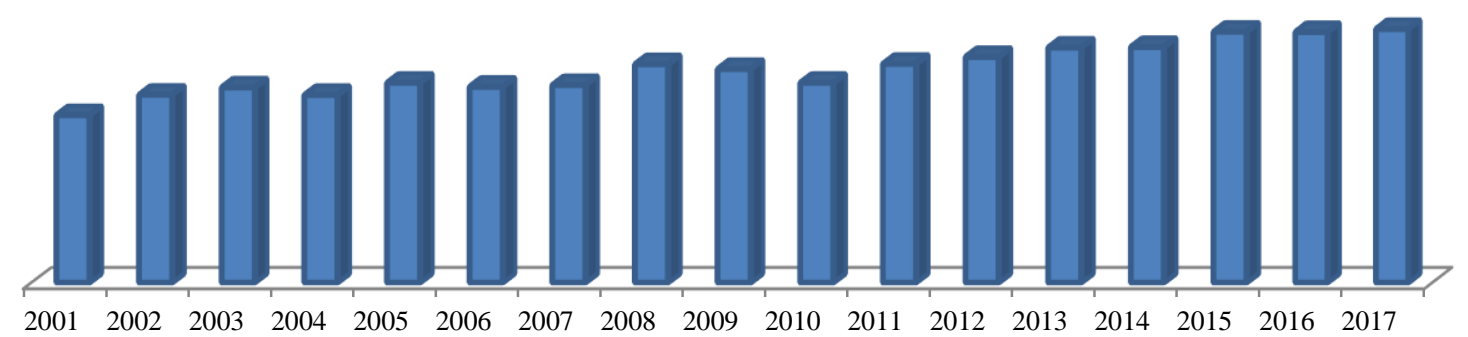

Figure 4. Change in tomato production in Turkey (Anonim 2018a).

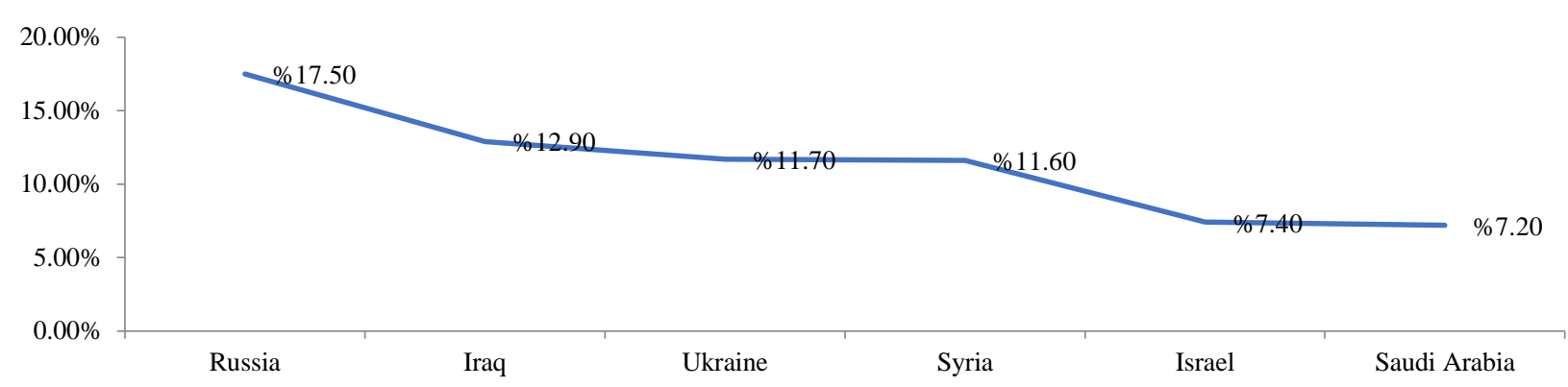

Figure 5. Leading tomato exporting countries in the world and their shares (\%)

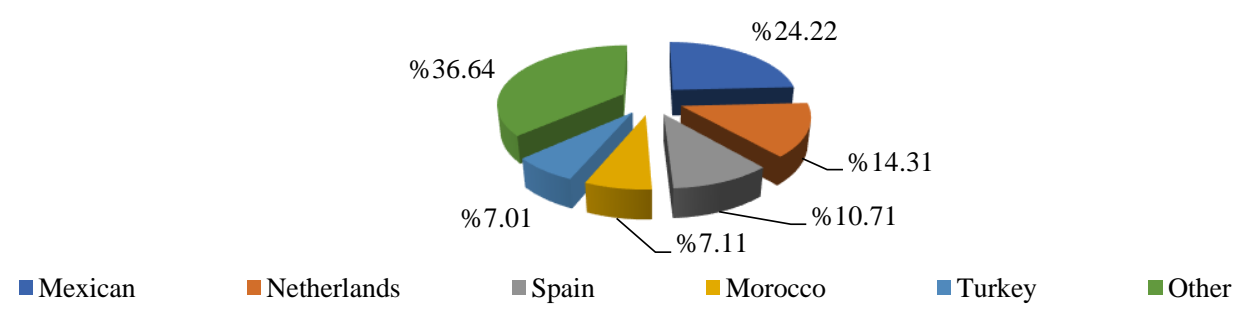

Figure 6. Leading Tomato Importing Countries in the World and Their Shares (\%) 


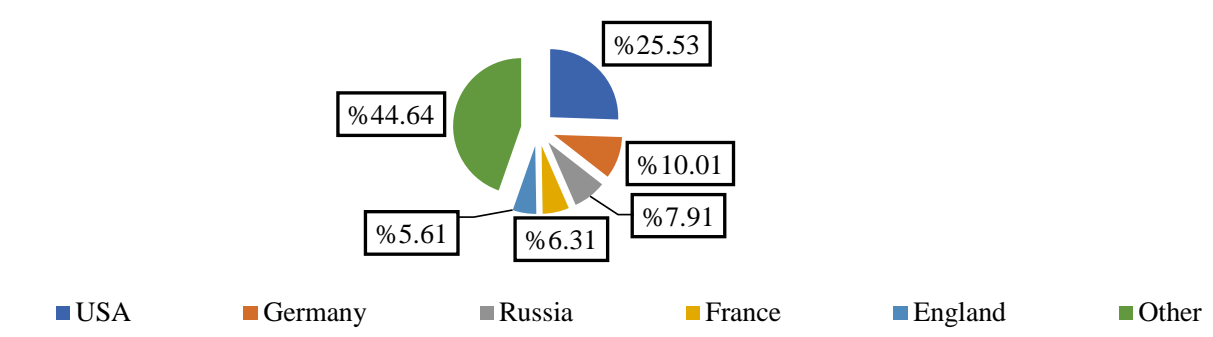

Figure 7. Important Countries İn Turkey's Tomato Export (2019*,\%)

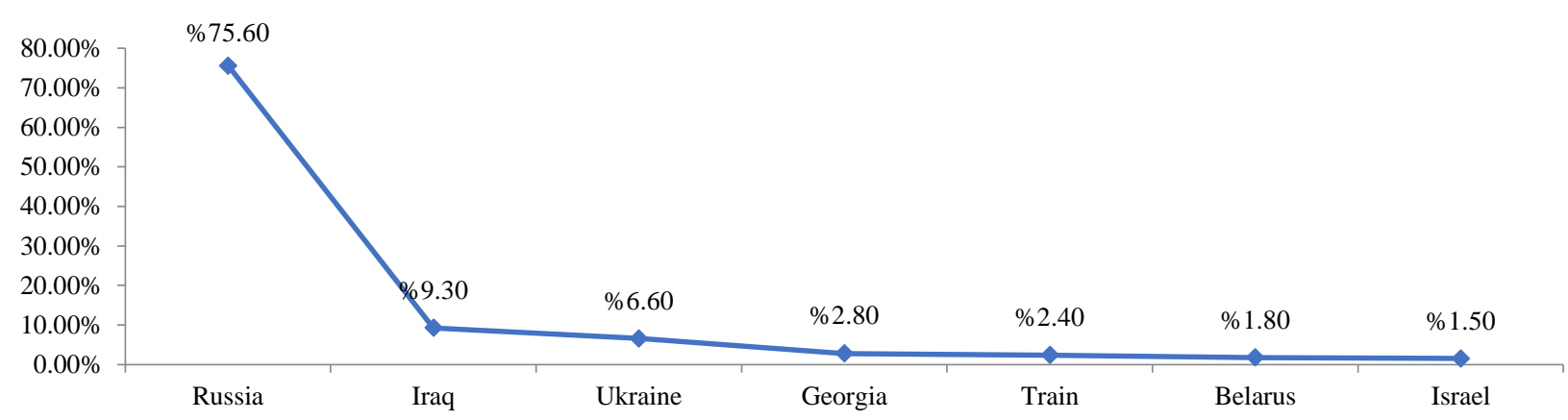

Figure 8. Important Countries İn Turkey’s Tomato Imports (2019*, \%)

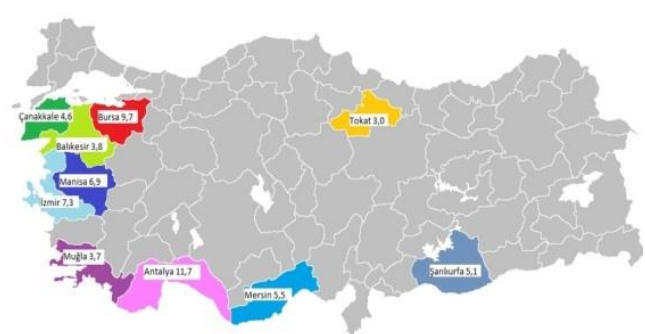

Figure 9. Tomato Planting Areas

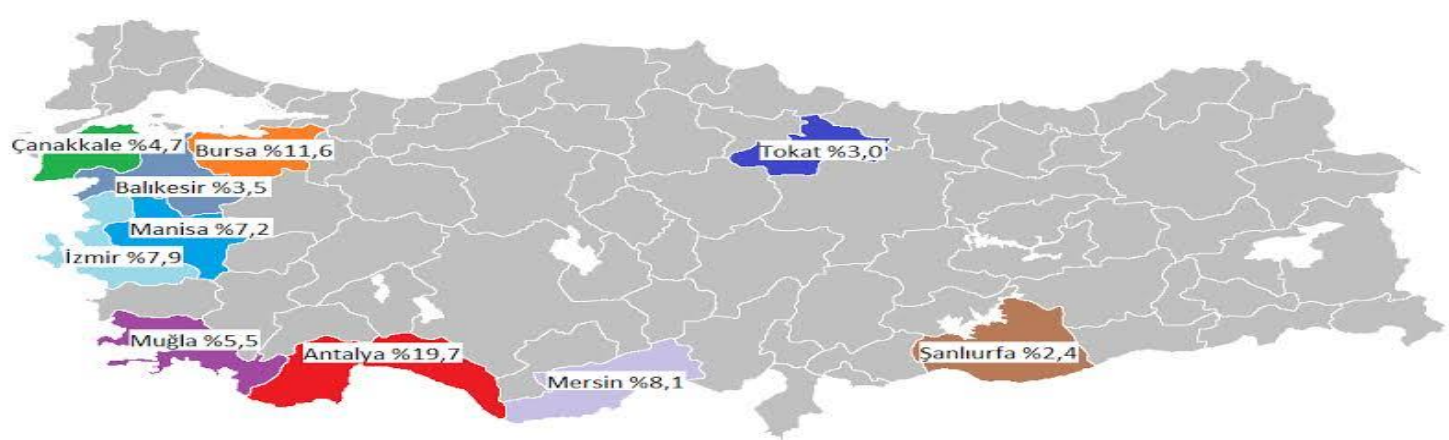

Figure 10. Tomato Production

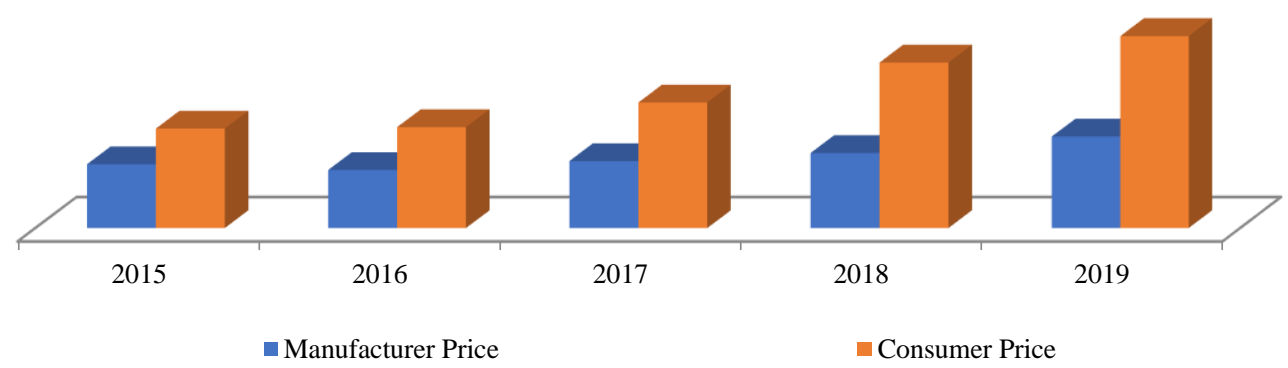

Figure 11. Tomato Producer And Consumer Prices (TUIK, 2020) 
Tomato is a type of vegetable that is imported as fresh and processed. Although it is difficult to reach comprehensive and accurate data on the tomato paste market in Turkey, it has been observed that there is an increasing trend in tomato paste imports in recent years, according to Table 3 data. (Table 3 ).

Since the amount of vegetables produced in Turkey is higher than the domestic market demand, it is important to evaluate the produced vegetables in foreign markets.According to the Mediterranean Exporters' Association report(Anonim 2017) in 2016 and 2017, Turkey's total vegetable exports were 1,076.9 and 1,268.0 thousand tons, respectively. (Tüzel et al., 2009). According to these data, $4 \%$ of our total vegetable production amount is evaluated in export. In the studies we carried out in previous years, it was determined that $5 \%$ of the vegetables produced were evaluated in export (Güvenç and Kaymak, 2008).

Tomato has an important share in vegetable exports. Tomatoes are among the products considered as fresh and processed in foreign trade. Tomatoes are used in foreign trade as fresh; tomato paste and peeled tomatoes. Although the export amount of fresh tomatoes changes from year to year, considering the last 4-5 years, it is around 500 thousand tons (Table 3) (Anonymous 2018c; Anonymous 2017).

When the tomato cultivation areas in Turkey are examined, Antalya, which has a share of $11.1 \%$ in the tomato cultivation areas in Turkey, ranks first with 201 thousand decares, Bursa ranks second with 190 thousand decares, and Manisa ranks third with 134 thousand decares. Tomato cultivation areas decreased by around 5\% in 2018 compared to 2017(Figure 9).

In 2018, Antalya ranked first with a tomato production of 2,410 thousand tons, Bursa took the second place with 1,575 thousand tons and Manisa took the third place with 975 thousand tons. The highest yield in Turkey is obtained in the Mediterranean Region as a natural result of climate advantage and being a greenhouse cultivation region. Tomato production in Turkey increased by $7 \%$ in 2018 compared to 2012 and reached 12.2 million tons. According to TUIK's plant production statistics, tomato production in 2019 increased by $5.7 \%$ compared to the previous year and amounted to 12.8 million tons (Figure 10).

Field-based diesel and fertilizer support to producers included in the farmer registration system in 2019 is 19 Turkish Lira(TL)/da, good agricultural practices support, 50 Turkish Lira(TL)/da for producers with individual good agricultural practices certificate, organic agriculture Support for tomatoes, which is among the 1st category products, is determined as 70 Turkish Lira(TL)/da for producers with individual product certificates and 100 Turkish Lira(TL)/da for small family businesses that produce crops (Figure 11).

Tomato producer price, which was $1.69 \mathrm{TL} / \mathrm{kg}$ in December 2019, increased by $6.3 \%$ compared to the previous month and decreased by $11 \%$ compared to the same month of the previous year. The average producer price in 2019 increased by $22 \%$ compared to 2018 and became 2.05 Turkish Lira (TL) $/ \mathrm{kg}$. The consumer price of tomatoes, which was 4.57 Turkish Lira (TL)/kg in December 2019, increased by $17.2 \%$ compared to the previous month and by $15 \%$ compared to the same month of the previous year. The consumer price in 2019 increased by $16 \%$ compared to 2018 and became 4.29 Turkish Lira (TL) $/ \mathrm{kg}$.

Considering the agricultural supports given to the producers for tomato cultivation, it is seen that the total support given has decreased by $2.5 \%$ from 2015 to 2019 . Looking at the support given in 2019, diesel support takes the biggest share. Although soil analysis support was not provided in 2016, in 2017, 2018 and 2019, soil analysis support was provided in agricultural lands of 50 decares or more, as 40 lira per analysis for each 50 decare of land (Table 4).

Tomato Input Parities in 2019, tomato producer price increased by $22 \%$ compared to the previous year. With the effect of this increase, certain increases were observed in the 2019 figures of tomato input parities, including the diesel price, compared to 2018. When prices are analyzed proportionally, tomato/fertilizer parity increased by $1.2 \%$, excluding supports, while tomato/diesel parity increased by $9.4 \%$ (Table 5 ).

Table 1. Production Change of Tomato Producing Countries for the Last 10 Years (FAO, 2018).

\begin{tabular}{l|cccc}
\hline \multicolumn{1}{c|}{ Country } & Production in 2001 & Production in 2018 & 2001/2018 Change (\%) & Country/World (\%) \\
\hline China & 24116217 & 61631581 & 155.6 & 33.82 \\
India & 7240000 & 19377000 & 167.6 & 10.63 \\
Nigeria & 1251003 & 3913993 & 212.9 & 2.15 \\
Turkey & 8425000 & 12150000 & 44.2 & 6.67 \\
Egypt & 6328720 & 6624733 & 4.7 & 3.63 \\
Abd & 10958809 & 12612139 & 15.1 & 6.92 \\
Italy & 6387889 & 5798103 & -9.2 & 3.18 \\
Iranian & 3009454 & 6577109 & 118.5 & 3.61 \\
Spain & 3971691 & 4768595 & 20.1 & 2.62 \\
Brazil & 3103363 & 4110242 & 32.4 & 2.26 \\
Mexican & 2737640 & 4559375 & 66.5 & 2.50 \\
Russia & 1713847 & 2899664 & 69.2 & 1.59 \\
Uzbekistan & 1014000 & 2284217 & 125.3 & 1.25 \\
World & 106715237 & 182256458 & 70.8 & 100.00 \\
\hline
\end{tabular}


Table 2. Turkey Tomato Data (Thousand Tons) (TUIK (08.01.2020) 1/Indicates the Change in the Last Two Marketing Years).

\begin{tabular}{l|rrrrrr}
\hline \multicolumn{1}{c|}{ Parameters } & \multicolumn{1}{c}{ 2013/14 } & \multicolumn{1}{c}{$2014 / 15$} & \multicolumn{1}{c}{$2015 / 16$} & \multicolumn{1}{c}{$2016 / 17$} & $2017 / 18$ & Change $(\%)$ \\
\hline Production & 11.820 & 11.850 & 12.615 & 12.600 & 12.750 & 1.2 \\
Consumption & 9.142 & 9.285 & 9.340 & 9.284 & 9.443 & 1.7 \\
Imports & 11.3 & 9.7 & 10.9 & 10.4 & 11.2 & 7.6 \\
Export & 1.259 & 1.127 & 1.195 & 1.246 & 1.205 & -3.3 \\
Consumption Per Person & 119.2 & 119.5 & 118.6 & 116.3 & 116.9 & 0.5 \\
\hline
\end{tabular}

Table 3. Turkey's Tomato Foreign Trade (Ton/Year)

\begin{tabular}{c|ccc|ccc}
\hline \multirow{2}{*}{ Years } & Fresh & Tomato Paste Peeled Tomatoes & Year & Fresh & Tomato Paste \\
\cline { 2 - 6 } & \multicolumn{3}{|c|}{ Export } & \multicolumn{3}{c}{ Imports } \\
\hline 2012 & 560,430 & 85,172 & 13,423 & 2012 & 132 & 252 \\
2013 & 483,046 & 111,515 & 11,397 & 2013 & 51 & 288 \\
2014 & 585,202 & 140,798 & 15,615 & 2014 & 107 & 349 \\
2015 & 541,355 & 118,639 & 12,379 & 2015 & 494 & 740 \\
2016 & 485,963 & 142,662 & 16,662 & 2016 & 787 & 306 \\
2017 & $526,1^{*}$ & - & - & & & \\
\hline
\end{tabular}

Table 4. Agricultural Supports Given to the Producer for Tomato Cultivation (TEPGE, TOB Data *2018 Yield İs Used).

\begin{tabular}{c|cccc}
\hline \multirow{2}{*}{ Years } & \multicolumn{4}{|c}{ Support Given } \\
\cline { 2 - 5 } & Soil Analysis & Fertilizer & Fuel & Total \\
\hline 2015 & 0.001 & 0.0018 & 0.0013 & 0.004 \\
2016 & - & & 0.002 & 0.002 \\
2017 & 0.001 & 0.001 & 0.001 & 0.003 \\
2018 & 0.001 & 0.001 & 0.001 & 0.003 \\
$2019 *$ & 0.001 & 0.001 & 0.002 & 0.004 \\
\hline
\end{tabular}

Table 5. Tomato Input Parities (BUGEM, TUIK and TEPGE, 2019).

\begin{tabular}{l|ccccc}
\hline \multicolumn{1}{c}{ Parameters } & 2015 & 2016 & 2017 & 2018 & 2019 \\
\hline Tomato Price (TL/kg) & 1.44 & 1.30 & 1.50 & 1.68 & 2.05 \\
Tomato Price + Support (TL/kg) & 1.44 & 1.30 & 1.50 & 1.68 & 2.05 \\
Fertilizer Price (TL/kg) (a.Sulphate 21\%) & 0.68 & 0.64 & 0.71 & 1.01 & 1.22 \\
Diesel Price (TL/lt) & 3.85 & 3.85 & 4.69 & 5.78 & 6.43 \\
\hline \multicolumn{7}{l}{ The amount of input that can be taken with 1 kg of tomatoes (kg) } \\
\hline Tomato/Fertilizer & 2.11 & 2.02 & 2.12 & 1.66 & 1.68 \\
Tomato +Support/Fertilizer & 2.12 & 2.02 & 2.12 & 1.66 & 1.68 \\
Tomato/Diesel & 0.37 & 0.34 & 0.32 & 0.29 & 0.32 \\
Tomato +Support/Diesel & 0.38 & 0.34 & 0.32 & 0.29 & 0.32 \\
\hline
\end{tabular}

\section{Findings and Discussion}

Among the countries examined within the scope of the research, Russia makes almost all of its tomato imports (75\%) from Turkey (Table 8 ). The reason for this is that it stopped importing tomatoes in other countries (AzerbaijanUzbekistan and Armenia) due to the diseases of tomato moth and eastern fruit moth pests. Therefore, there is a significant commercial concentration.

In the last 3 years, it has started to decrease by falling below 1. It has fallen below 1 in the last 3 years. The reason of this; Russia decided to embargo Turkish tomatoes after the political crisis with Turkey in November 2015. In November 2017, Turkish tomatoes got an export visa to Russia again, but had a quota problem. The quota, which was 100 thousand tons in 2017, was increased to 200 thousand tons after 150 thousand tons in 2020. When the following period data is calculated, it is predicted that the commercial concentration with Russia will increase. One of Turkey's important markets is Ukraine. Ukraine has generally increased its import value in the last 18 years and Turkey's market share has likewise increased. The concentration coefficient has never fallen below 1 in the last 18 years (Table 8 ).

The reason of this; Ukraine is an important agricultural country with its large and fertile agricultural lands, but the country has not been able to show its current potential due to the fact that the country has not yet made the desired investments in the sector. In the last months of 2019, 15 tons and 38 tons of tomatoes were returned from Ukraine because they contain harmful substances (South African Moth). Agreements signed with the European Union are expected to adversely affect Turkey's exports of agricultural products to Ukraine.

One of Turkey's other important markets is Saudi Arabia. Saudi Arabia has generally kept its import value at certain levels in the last 18 years, and Turkey's market share has likewise increased. In the last 18 years, the concentration coefficients have decreased below 1(one) in 2009-2016 (Table 8). This is because they prefer tomatoes that are resistant to long-term storage. They prefer greenhouse tomatoes densely. 
Table 6. Tomato Foreign Trade of Major Countries (1000 USD).

\begin{tabular}{|c|c|c|c|c|}
\hline Years & World TI. & Turkey TE. & Russia TI. & Turkey's TE. to Russia \\
\hline 2001 & 302894 & 190768 & 60615 & 15.208 \\
\hline 2002 & 357077 & 244038 & 63992 & 28.713 \\
\hline 2003 & 426361 & 227400 & 89617 & 32.253 \\
\hline 2004 & 444057 & 235364 & 139478 & 58.296 \\
\hline 2005 & 510302 & 250182 & 216169 & 59.148 \\
\hline 2006 & 560726 & 304372 & 298395 & 97.736 \\
\hline 2007 & 696044 & 372094 & 534742 & 172.487 \\
\hline 2008 & 733949 & 439729 & 628923 & 247.194 \\
\hline 2009 & 722322 & 542259 & 648885 & 197.128 \\
\hline 2010 & 846992 & 574279 & 773582 & 247.699 \\
\hline 2011 & 859365 & 576573 & 814072 & 258.495 \\
\hline 2012 & 847126 & 560430 & 886816 & 255.200 \\
\hline 2013 & 909007 & 483046 & 110445 & 274.596 \\
\hline 2014 & 920627 & 585202 & 104471 & 275.921 \\
\hline 2015 & 849230 & 541355 & 676380 & 258.815 \\
\hline 2016 & 870955 & 485963 & 490582 & 0 \\
\hline 2017 & 915465 & 522876 & 558745 & 2.155 \\
\hline 2018 & 944461 & 525874 & 630575 & 30.454 \\
\hline Years & Iraq TI. & Turkey's TE. to Iraq & Ukraine TI. & Turkey's to Ukraine TE. \\
\hline 2001 & 1200 & 0 & 276 & 92 \\
\hline 2002 & 179 & 0 & 218 & 108 \\
\hline 2003 & 8660 & 171 & 83 & 117 \\
\hline 2004 & 8584 & 198 & 105 & 184 \\
\hline 2005 & 20647 & 236 & 302 & 445 \\
\hline 2006 & 61870 & 340 & 1337 & 898 \\
\hline 2007 & 129418 & 474 & 1338 & 2.032 \\
\hline 2008 & 82640 & 3.160 & 21295 & 13.339 \\
\hline 2009 & 159068 & 4.892 & 33274 & 24.590 \\
\hline 2010 & 322032 & 3.457 & 35680 & 19.770 \\
\hline 2011 & 52758 & 8.732 & 43247 & 24.061 \\
\hline 2012 & 60698 & 19.972 & 66669 & 26.010 \\
\hline 2013 & 81695 & 8.378 & 81052 & 30.250 \\
\hline 2014 & 67841 & 16.993 & 55546 & 24.499 \\
\hline 2015 & 162428 & 11.021 & 19611 & 8.263 \\
\hline 2016 & 163970 & 32.464 & 29536 & 16.953 \\
\hline 2017 & 139710 & 25.299 & 23099 & 14.916 \\
\hline 2018 & 218426 & 16.223 & 37154 & 25.302 \\
\hline
\end{tabular}

TI: Tomato Import, TE: Tomato Exports

Table 7. Tomato Foreign Trade of Major Countries (1000 USD).

\begin{tabular}{c|cccccc}
\hline Years & \multicolumn{5}{c}{ Syrian TI. Turkey’s TE. to Syria Israel TI. Turkey’s TE. to Israel Saudi Arabia TI. Turkey’s Saudi to Arabia TE. } \\
\hline 2001 & 0 & 0 & 139 & 0 & 42522 & 11113 \\
2002 & 1010 & 0 & 736 & 409 & 62232 & 10512 \\
2003 & 368 & 0 & 33 & 0 & 54997 & 12177 \\
2004 & 1103 & 0 & 10 & 0 & 29082 & 7200 \\
2005 & 28545 & 0 & 20 & 0 & 27898 & 5831 \\
2006 & 7271 & 0 & 0 & 0 & 40621 & 4862 \\
2007 & 17388 & 0 & 203 & 0 & 55932 & 5746 \\
2008 & 14337 & 5 & 927 & 68 & 10004 & 6764 \\
2009 & 30346 & 97 & 0 & 0 & 62006 & 8873 \\
2010 & 23968 & 10 & 377 & 0 & 81584 & 7373 \\
2011 & 69559 & 94 & 367 & 0 & 61751 & 10416 \\
2012 & 58013 & 340 & 189 & 0 & 70973 & 11304 \\
2013 & 56396 & 1,267 & 432 & 0 & 59024 & 7543 \\
2014 & 41978 & 1,658 & 1316 & 18 & 74837 & 5134 \\
2015 & 30396 & 2,479 & 11694 & 9,068 & 93308 & 12,305 \\
2016 & 4431 & 3,976 & 16720 & 13,896 & 98381 & 26,876 \\
2017 & 10570 & 9,438 & 17317 & 14,606 & 69836 & 24,918 \\
2018 & 11697 & 10,401 & 21301 & 18,791 & 79110 & 20,639 \\
\hline
\end{tabular}

TI: Tomato Import, TE: Tomato Exports 
Table 8. Concentration Coefficients of Countries

\begin{tabular}{l|cccccc}
\hline Years & Russia & Iraq & Ukraine & Syria & Israel & Saudi Arabia \\
\hline 2001 & 4.0 & 0.00 & 5.29 & 0.00 & 0 & 6.56 \\
2002 & 6.6 & 0.00 & 7.25 & 0.00 & 8.13 & 2.57 \\
2003 & 6.7 & 0.37 & 26.43 & 0.00 & 0 & 3.28 \\
2004 & 7.9 & 0.44 & 33.06 & 0.00 & 0 & 3.14 \\
2005 & 5.6 & 0.23 & 30.06 & 0.00 & 0 & 3.74 \\
2006 & 6.0 & 0.10 & 12.37 & 0.00 & 0 & 0.00 \\
2007 & 6.0 & 0.07 & 28.41 & 0.00 & 0 & 1.70 \\
2008 & 6.6 & 0.64 & 10.46 & 0.01 & 1.22 & 10.31 \\
2009 & 4.0 & 0.41 & 9.84 & 0.04 & 0 & 0.00 \\
2010 & 4.7 & 0.16 & 8.17 & 0.01 & 0 & 1.91 \\
2011 & 4.7 & 2.47 & 8.29 & 0.02 & 0 & 3.56 \\
2012 & 4.3 & 4.97 & 5.90 & 0.09 & 0 & 3.66 \\
2013 & 4.7 & 1.93 & 7.02 & 0.42 & 0 & 2.73 \\
2014 & 4.2 & 3.94 & 6.94 & 0.62 & 0.22 & 1.65 \\
2015 & 6.0 & 1.06 & 6.61 & 1.28 & 12.16 & 2.20 \\
2016 & 0.0 & 3.55 & 10.29 & 16.08 & 14.90 & 0.00 \\
2017 & 0.1 & 3.17 & 11.31 & 15.63 & 14.77 & 528.39 \\
2018 & 0.9 & 1.33 & 12.23 & 15.97 & 15.84 & 30.08 \\
\hline
\end{tabular}

When the data between Turkey and Iraq, which is another important market, are examined; The concentration coefficients of Turkey and Iraq has exceeded 1(one) as of 2011. The export performance in the Iraqi market, which has an important place in Turkey's tomato import, is low as can be seen from the concentration coefficients (Table 8). The reason of this; Iraq imposes restrictions on all countries due to the sufficient seasonal production of fresh tomatoes at certain times each year. However, this practice in force has now been abolished and trade concentration with Iraq is expected to increase.

Tomato trade between Turkey and Syria started in 2012. The export performance in the Syrian market, which is also at low levels in Turkish tomato imports, is very low as can be seen from the concentration coefficients, reaching high levels in the last 3 years (Table 8). The reason of this; The negative political relations between Russia and Syria are due to the fact that the TurkishRussian leaders, who can come to terms on complex and critical issues, cannot agree on a single tomato issue. The export performance is low due to the high Turkey-Russia tomato trade and the fact that Syria imports the tomatoes exported from Turkey to other countries.

Tomato trade between Turkey and Israel started in 2013. The export performance in the Israeli market, which is also at very low levels in Turkish tomato imports, is very low as can be seen from the concentration coefficients, reaching high levels in the last 4 years (Table 8 ). The reason of this; The fact that it requires agricultural quarantine inspection in fresh fruit and vegetable production areas is a technical barrier to trade. Export performance is expected to decrease with Israel, whose hybrid seed production has increased in recent years.

Turkey has risen to the top of the world in tomato production with the climate conditions being suitable for tomato cultivation and the development of the tomato processing industry since the 1970 s Tomato, which is an important vegetable in terms of nutrition, takes the first place in vegetable agriculture and is grown in the open and under cover.
12.1 tons of tomatoes are produced in Turkey, of which 8.4 tons are for table and 3.7 tons for tomato paste. Greenhouse vegetable cultivation has an important place in Turkey agriculture sector, as it provides high yield and income from the unit area, and also provides a regular labor force throughout the year by spreading plant production to all seasons of the year.

Among the vegetables grown in Turkey's, the most produced vegetable is tomato. Per capita consumption has varied between $115-120 \mathrm{~kg} / \mathrm{year}$ in recent years and was determined as $116.9 \mathrm{~kg} /$ year in 2018 . The tomato export, which was 250 thousand tons in 2005, showed an increasing trend, although it changed from year to year, and reached 576 thousand tons in 2011, more than doubled.

The decrease in tomato cultivation areas and the decrease in yield due to tomato moth had a negative impact on tomato production. Tomato exports in Turkey showed a decrease of $2,05 \%$ with 486 thousand tons in 2016, and in 2019 , a decrease of $11,3 \%$ with 470 thousand tons.

In this study, we evaluated Turkey's place in the world tomato trade. In addition, we analysed the change in the value and direction of the trade flow between Turkey and tomato importing countries on an annual basis. According to the results of the examination, Turkey has a competitive power in tomato trade. During the period under review, Turkey's competitiveness in the tomato trade has gradually increased, although it changes over the years. However, Turkey's competitiveness in tomato product has been declining since 2010.

Turkey's tomato exports to these markets have decreased as a result of the weak growth trend of Russia and European economies, which are Turkey's most important trade partners. Therefore, Turkey's competitiveness in tomato trade has been weakening in recent years. In order to increase Turkey's competitiveness in the global market, it is important to increase the share of products with higher added value in exports and to make logistics and marketing chains effective.

In order to increase the competitiveness of the sector, export-based government incentive policies should be implemented effectively. 


\section{Conclusion and Recommendations}

Compared to agricultural products, vegetables are more labour-intensive products. For this reason, it is necessary to focus on products with high export opportunities in vegetable types. Tomato is one of these products. According to the analysis, tomato is an advantageous vegetable in terms of production, export and competition. It is important that this advantage is sustainable.

For this reason, modern techniques should be used in order to meet the standards of national and international markets at every stage of tomato production, and product products obtained from tomatoes with high added value should be encouraged as well as foreign trade as fresh.

Considering the analyses, tomato exports should be reevaluated within the framework of general policies. The decrease in export performance can be caused by diseases, pests, growing in the wrong conditions, etc. stems from political issues rather than such issues. Therefore; The reality of how important regional peace is for the Turkish economy is once again revealed.

On the other hand, the changing balances in the international market with the Covid-19 epidemic started to signal that this situation would not continue for a long time. It has been discussed that the supply problem in Russia in the early stages of the epidemic will be solved by importing from Turkey.

The threat of the virus has increased the demand for Turkish products in e-export by 5 times, and countries that import vegetables and fruits from China have turned to the Turkish market. Russia is one of these countries. For the first time in years, Moscow has prepared a draft resolution to increase the import of tomatoes from Turkey to 200 thousand tons. After the Chinese border was closed to crossings, Russian authorities announced that they would turn to the Turkish market.

Emphasizing that exports will increase due to the epidemic, leading representatives of the industry also pointed out that prices in the domestic market may increase.

Countries consider food adequacy within the country rather than being active in the market, considering that there may be food shortages due to the epidemic. For this reason, new countries do not enter the world market for tomato exports, but import them from Turkey. This is a sign that our competitive power will increase.

\section{References}

Altay B, Gürpınar K. 2008. Announced comparative advantages and some competitiveness indices: an application on the Turkish furniture industry, Afyon Kocatepe University İ.İ.B.F: Journal, 10(1):257-274. Retrieved from https:// dergipark.org.tr/tr/pub/akuiibfd/issue/1629/20432

Anonymous 2017. Mediterranean Fresh Fruit and Vegetable Exporters' Association (AKIBB) Working Report 2017, Yenişehir Mersin, P:22

Arısoy H, Bayramoglu Z, Celik Y, Ozer OO. 2014. Regional concentration of Turkish dried fruits exports. Turkish Journal of Agriculture and Natural Sciences 1(2): 269-280.

Arısoy H, Aras İ, Kaya MF. 2018. Regional Concentration Situation in Turkey's Apple Foreign Trade, Yüzüncü Y1l Üniversitesi Tarım Bilimleri Dergisi, 29(2): 242-252.
Bashimov G. 2016. Turkey's Tomato Export Performance and Competitiveness. Alinteri Magazine, 31(B): 1-8

Bayramoğlu Z, Celik Y, Oguz C. 2009. Current situation of apple production and development possibilities in Konya Province, Journal of Agricultural Sciences, 2(1): 11-15

Celik S, Ozbay N. 2015. Analysis of Production-Price Relationship in Tomato Production with Almon Delay Model: The Case of Turkey, Turkish Journal of Agricultural and Natural Sciences, 2(2): 207-213

Eraktan G, Arısoy H. 2012. Turkey's Fresh Fruit and Vegetable Exports - Current Situation, Problems and Solution Suggestions. Istanbul Chamber of Commerce Publications Sectoral Studies and Research, Publication No:2010-92, ISBN:978-9944-60-865-7 (Printed), ISBN:978-9944-60866-4 (Electronic).

Erkan B. 2012. Specialization level of Turkey's traditional exported agricultural products, Journal of Social and Human Sciences (Online), 4(1): 75-83

Erturk YE, Cirka M. 2015. Tomato production and marketing in Turkey and the North East Anatolian Region (KDAB), YYÜ Journal of Agricultural Sciences, 25(1): 84-97, doi: 10. 29133/yyutbd.236256

Guvenc I, Kaymak HC. 2008. Change, Requirement and Projection in Vegetable Production and Consumption in Turkey. Alinteri, 15(B): 40-45.

Guvenc I, Alan R. 1994a. Vegetable export of Turkey to Middle East Countries. Journal of Atatürk University Faculty of Agriculture, 25(2): 269-274

Guvenc I, Alan R. 1994b. Vegetable Export of Turkey to European Community Countries. Journal of Atatürk University Faculty of Agriculture, 25(1): 94-99.

Guvenc I. 2017. Vegetable Growing: Basic Information, Conservation and Cultivation. Nobel Publications, P: 288

Kaymak HC, Guvenc I, Dursun A. 2005. Current situation of vegetable agriculture in Turkey, some important developments and solution suggestions. Journal of Atatürk University Faculty of Agriculture, 36(2): 221-228.

Keskin G. 2010. Price changes in tomato paste industry and domestic market in Turkey, YYU Journal of Agricultural Sciences, 20(3): 214-221.

Keskin G. 2012. Tomato and Tomato Paste Status-Forecast: 2012/2013, Agricultural Economy and Policy Development Institute, Publication No: 219, Ankara

Koc D. 2005. Developments Affecting Fresh Fruit and Vegetable Trade and Analysis of Turkey's Competitive Advantage, T.R. Prime Ministry Undersecretariat of Foreign Trade Export Development Study Center, Ankara.

FAO, 2018. Food and Agriculture Organization of the United Nations. FAOSTAT. Accessed from: http://www.fao.org/faostat/en\#data/QC [Accessed September 21, 2021]

ITC, 2018. International Trade Center, Trade Statistics. Access: http://www.itcturkiye.com/tr. [Accessed 20 September 2021]

TOB, 2018. Ministry of Agriculture and Forestry. 2019 Annual Report. Access: https://www.tobb.org.tr [Accessed 15 September 2021]

TUIK, 2018. Turkish Statistical Institute Foreign Trade Statistics. Access: https://data.tuik.gov.tr/Kategori/GetKategori?p= Foreign-Trade-104. [Accessed 12 August 2021]

TURKTOB, 2017. Journal of the Turkish Seed Association. Access: http://www.turktob.org.tr/tr/turktob magazine TTOB_Dergi17_WEB-8_13.pdf. [Accessed 10 July 2021]

Tuzel Y, Duyar H, Öztekin GB, Gül A. 2009. The effects of tomato rootstocks on plant growth, temperature sum demand, yield and quality at different planting dates, Journal of Ege University Faculty of Agriculture, 46(2): 79-92. Retrieved from https://dergipark.org.tr/tr/pub/zfdergi/issue/5094/69575 